\title{
Review Paper: Characteristics of Grammar in Children With Autism Spectrum Disorder: A Narrative Review of Evidence
}

\author{
Saeide Beytollahi ${ }^{1} \mathbb{B}$, Zahra Soleymani $^{{ }^{*}}$ (D)
}

1. Department of Speech Therapy, School of Rehabilitation, Tehran University of Medical Sciences, Tehran, Iran

\begin{tabular}{|c|c|}
\hline $\begin{array}{l}\text { Use yur device to scan } \\
\text { and read the eartic online }\end{array}$ & \\
\hline 口及 & \\
\hline 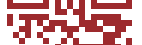 & Review of Evidence Journal of Modern Rehabilitation. 2019; 15(2):65-/8. http://dx.dol.org/10.32598/JMR.13.2.65 \\
\hline 口ift: & doijhttp://dx.doi.org/10.32598/JMR.13.2.65 \\
\hline
\end{tabular}

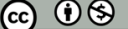

Article info:

Received: 10 Oct 2018

Accepted: 20 Jan 2019

Available Online: 01 Apr 2019

Keywords:

Autism Spectrum Disorder, Grammar, Syntax,

Morphology, Morphosyntax

\begin{abstract}
A B S T RACT
Introduction: One of the prevalent developmental disorders is Autism Spectrum Disorder (ASD). Some children with ASD have language impairments besides communication disorders. Although the main linguistic impairment in this group has been reported in their pragmatic ability, some other linguistic elements such as grammar might be impaired, too. The primary purpose of this narrative review was to study the grammatical characteristics of children with ASD.
\end{abstract}

Materials and Methods: To find the related documents with this narrative review, we adopted 114 papers from the databases of Google Scholar, Web of Knowledge, Scopus, and PubMed. Out of these, 48 papers were selected to be studied.

Results: The studies grouped into four: group of comparing grammatical characteristics of children with ASD and typically-developing children, group of comparing grammatical characteristics of children with ASD and individuals with specific language impairments, group of investigating the relationship between grammar and the theory of mind in children with $\mathrm{ASD}$, and group of processing basis of grammar in ASD children that is named developmental language disorder recently after specific language disorder.

Conclusion: The studies reported conflicting results because of two main factors: differences in the types of studies and heterogeneity of the ASD group. Thus, some children with ASD show grammar impairments and need precise assessment for proper intervention and treatment.

\section{Introduction}

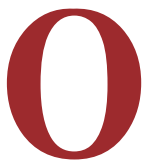

ne of the pervasive developmental disorders is Autism Spectrum Disorder (ASD), in which the individuals show significant impairments in non-verbal communication ability with some possible language deficiencies [1]. The most impaired aspect of language is a pragmatic ability, especially conversational skills which are unsuitable and abnormal [2]. However, they may function very well in comprehension and expression of single words, even much better than their TypicallyDeveloping (TD) peers. Therefore, the children with ASD are categorized into two subgroups: the ASD children

* Corresponding Author:

Zahra Soleymani, PhD.

Address: Department of Speech Therapy, School of Rehabilitation, Tehran University of Medical Sciences, Tehran, Iran.

Tel: +98 (912) 2036683

E-mail:soleymaniz@tums.ac.ir 
with and without language impairments [3]. Language skills in ASD children with language impairments are significantly different from one child to another. On one side of the spectrum, there are children with relatively common lexical knowledge, appropriate grammar, and normal speech production, and on the other side, there are nonverbal children [4]. The range and the type of these language impairments are the topics of investigation in many studies. Clarifying these topics helps to know this group better and plan a more effective intervention.

Grammar is one of the language elements playing an important role in verbal communication and may be impaired in children with ASD. To make a multi-word sentence, we need a series of rules called grammar. A child will be unable to use grammar unless his or her lexicon reaches a certain volume which is reported from 50 to 100 words at the age of two. For a child, it takes several years to use all complicated rules to combine words. The evidence shows that the overgeneralized formats in the English language like "goed" or "comed" repeatedly appear in the TD children's conversation indicating that the child as a hypothesis-generator plays an active role in learning grammar and confirms that the child is learning a rule-governed system. The child is unable to learn the grammatical structures through the word by word repetition [5]. This process may be impaired in children with
ASD. Therefore, the present study aimed to review and compare the grammatical characteristics in children with ASD

Only non-experimental studies were included in this review that employed a grammatical comparison between children with ASD and other children, both TD children and children with language impairments, and all of grammatical structures and topics about grammar. The age range of children was not an inclusion criterion, but the native language of children was English.

At first, the search strategy was based on selecting terms for grammar to rely on textbooks about language development. Advanced search techniques were used, based on the following keywords: "grammar", "syntax", "morphology", and "morphosyntax". Each of these keywords was searched accompanied by "autism" through the electronic databases of Google Scholar, ISI Web of Knowledge, Scopus, and PubMed from 1975 to December 2017. One hundred and fourteen articles were obtained out of the initial search. In the next step, 48 records remained after deleting similar and unrelated articles because some of the studies had been indexed on two or more electronic databases.

Then the articles were examined in terms of the association between the "Abstract" and the goal of our study.

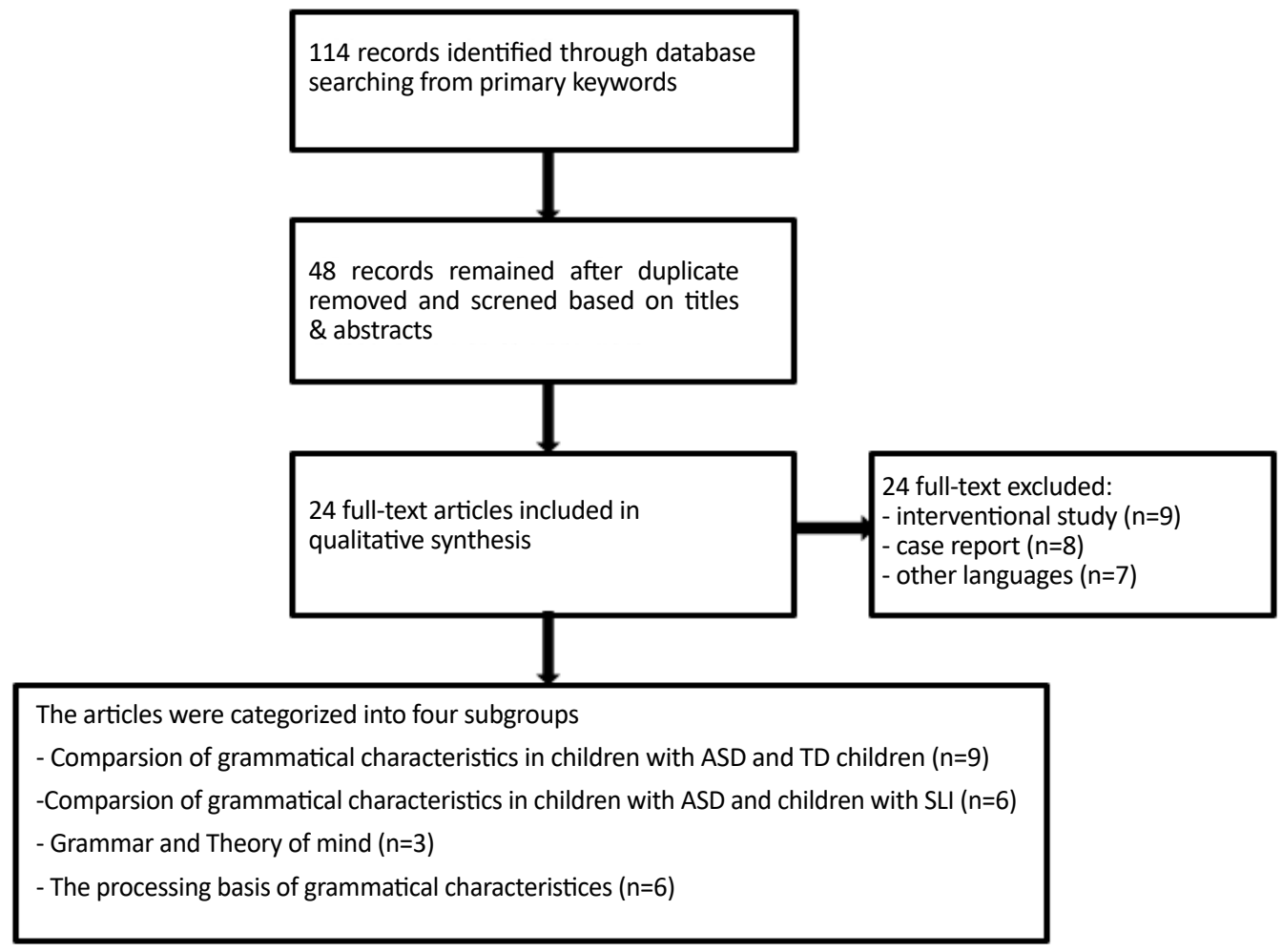

Figure 1. Flow chart of information through the literature review 
The articles that studied the effect of an intervention on grammar in children with ASD and case reports were omitted. Finally, 24 articles related to the study of grammar in children with ASD were selected.

The chosen articles were studied precisely and categorized into four groups: The first group included the studies comparing the grammatical characteristics of children with ASD and TD children and rarely compared with the other language disorders. The second group studied and compared the grammatical characteristics of children with ASD and children with Specific Language Impairment (SLI) as a group with the main sign of grammar deficiency. The third group discussed the association between grammar and Theory of Mind (TOM) as one of the primary impaired abilities in children with ASD, and the fourth group included the studies dealing with the cognitive processing role as the basis of the grammatical deficiencies in children with ASD.

\section{Results}

A total of 24 studies about grammar in children with ASD were chosen and used for the review. Table 1 summarizes the characteristics of these selected articles.

Comparing grammatical characteristics between children with autism spectrum disorder and typically-developing children

One of the methods for studying the grammatical characteristics of children with ASD is to compare these children with TD children or children with other disorders that have language impairments. Generally, the obtained results from previous studies were categorized into three groups. The first group of studies indicated that the grammar development and the grammatical characteristics of children with ASD were similar to the TD children and their problems caused by pragmatic impairments and organization deficiencies in lexical/ semantic areas [6].

Tager-Flusberg and Calkins [7], in a linear study, investigated the language learning process in children with ASD, Down syndrome, and TD children. Based on the Index of Production Syntax (IPsyn), they reported that the growth pattern of the children with ASD is similar to the other two groups. The second group of studies showed grammar impairments in children with ASD, even those who did not have a delay in the primary grammar development [8]. Eigsti, Bennetto, and Dadlani [9], through the free game, gathered the conversation samples of children with ASD, children with developmental delay, and TD children.
Then, their sentence length, IPsyn, and the grammatical errors were compared. The obtained results indicated the syntax deficiencies in children with ASD, and they used more simple language structures, although the groups were homogenized in terms of word knowledge and nonverbal intelligence.

The drawbacks of this study were the data gathering method because the conversation is considered the main problem of children with ASD, and observed differences might be caused by the pragmatic disorder not a grammatical deficiency. For this reason, in another study, Eigsti and Bennetto [10] used the grammar judgment task for data gathering that decreases the communicational needs. In this task, several sentences are presented to the participants with or without grammatical errors. These sentences need short participant's answers (yes/ no). They reported that the children with ASD were able to do this task, and there were significant differences in the singular third person, present continuous tense, and simple past tense in comparison with the control group.

Finally, the third group of studies suggests that the children with ASD are a heterogeneous group; some of them show grammar deficiency while some others have age-appropriate grammar. Therefore, grammatical skills are not considered as a marker for the diagnosis of autism [11]. Rapin and Dunn [12] compared 300 children with ASD between ages 2 to 5 years with 262 children with language developmental disorders. They suggested that children with ASD were categorized in two subgroups: 1. The mixed expressive/receptive subgroup (impaired syntax and phonology with limited lexicon); and 2. The fluent semantic/pragmatic subgroup (the weak conversational skills and pragmatic disorder without syntax and phonology deficiencies). They believed that ageappropriate phonology and syntax play a significant role in the communication of children with ASD.

\section{Morphemes}

There are a few studies about morphemes development in children with ASD. Fein and Waterhouse [13] reported no difference between children with ASD and TD children in the learning development of the grammatical morphemes. Several studies $[14,15]$ reported that children with ASD not only had a delay in language development but also used simpler morphology rules. They deleted more morphemes the same as a mentally-disabled group. 
Table 1. Summary of selected studies on grammatical characteristics of children with ASD

\begin{tabular}{|c|c|c|c|c|c|}
\hline Authors & Title & Journal (year) & Country & The Subgroup of Study & Conclusions \\
\hline $\begin{array}{c}\text { Walenski et } \\
\text { al. [3] }\end{array}$ & $\begin{array}{l}\text { Inflectional } \\
\text { morphology in } \\
\text { high-functioning } \\
\text { autism: Evidence for } \\
\text { speeded grammati- } \\
\text { cal processing }\end{array}$ & $\begin{array}{l}\text { Research in Autism } \\
\text { Spectrum Disorder } \\
(2014)\end{array}$ & USA & $\begin{array}{c}\text { Comparison between } \\
\text { groups }\end{array}$ & $\begin{array}{l}\text { When children with autism } \\
\text { show apparently normal, } \\
\text { processes, and or brain } \\
\text { structures subserving } \\
\text { language may be atypical } \\
\text { in this disorder. }\end{array}$ \\
\hline $\begin{array}{l}\text { Eigsti, Ben- } \\
\text { netto, and } \\
\text { Dadlani [6] }\end{array}$ & $\begin{array}{l}\text { Beyond pragmatics: } \\
\text { Morphosyntactic de- } \\
\text { velopment in autism }\end{array}$ & $\begin{array}{l}\text { Journal of Autism } \\
\text { and Developmental } \\
\text { Disorder (2007) }\end{array}$ & USA & $\begin{array}{c}\text { Comparison between } \\
\text { groups }\end{array}$ & $\begin{array}{l}\text { There is a highly specific } \\
\text { pattern of language im- } \\
\text { pairments, and impor- } \\
\text { tantly, syntactic delays, } \\
\text { in a group of children } \\
\text { with autism. }\end{array}$ \\
\hline $\begin{array}{c}\text { Eigsti and } \\
\text { Bennetto [7] }\end{array}$ & $\begin{array}{l}\text { Grammaticality judg- } \\
\text { ments in autism: } \\
\text { Deviance or delay }\end{array}$ & $\begin{array}{l}\text { Journal of Child Lan- } \\
\text { guage (2009) }\end{array}$ & USA & $\begin{array}{c}\text { Comparison between } \\
\text { groups }\end{array}$ & $\begin{array}{l}\text { Participants with autism } \\
\text { were significantly less } \\
\text { sensitive than controls, } \\
\text { specifically for the third } \\
\text { person singular and pres- } \\
\text { ent progressive marking. }\end{array}$ \\
\hline $\begin{array}{l}\text { Wittke et al. } \\
{[8]}\end{array}$ & $\begin{array}{l}\text { Grammatical lan- } \\
\text { guage impairment in } \\
\text { autism spectrum dis- } \\
\text { order: Exploring lan- } \\
\text { guage phenotypes } \\
\text { beyond standardized } \\
\text { testing }\end{array}$ & $\begin{array}{l}\text { Frontiers in Psychology } \\
\qquad(2017)\end{array}$ & USA & $\begin{array}{c}\text { Comparison between } \\
\text { groups }\end{array}$ & $\begin{array}{l}\text { Children with ASD can } \\
\text { be categorized into three } \\
\text { subgroups: Those with } \\
\text { normal language, those } \\
\text { with marked difficulty } \\
\text { in grammatical produc- } \\
\text { tion but relatively intact } \\
\text { vocabulary, and those } \\
\text { with more globally low } \\
\text { language abilities. }\end{array}$ \\
\hline
\end{tabular}

A syntactic inves-

Pierce and tigation of verbal

autistic, mentally retarded, and normal children

\section{Journal of Autism and \\ Childhood Schizoph nia (1997) \\ Canada Comparison between groups}

It appears that the syntactic abnormalities and characteristic of autism are attributable to an extreme delay in language development as well as to an impaired ability to make use of linguistic rules.

It is suggested that func tors in autistic subjects may develop in an atypica but consistent order, and this may be due to specific semantic deficits, particularly in the areas of person and time deixis.

Pierce, and studies of grammatiStreiner [10] autistic and mentally retarded children
Journal of Autism developmenta

Disorder (1980)
Canada groups
Dissociations in

form and function

Tager-flusberg in the acquisition of

[11]

language by autistic children. Constraints on language acquisition

\section{Studies of Atypical Children (1994) \\ USA \\ Comparison between groups}

The problems of children with autism in using the Wh-questions have more resulted from the pragmatic disorders because their questions were generally formed well grammatically.

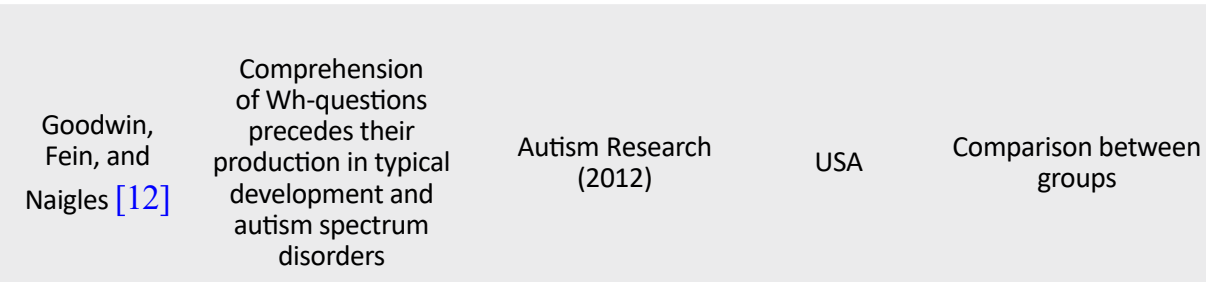

Comprehension of the subject- and object-whquestions was delayed in children with ASD compared with age-matched TD children, but not when matched on overall language levels. 


\begin{tabular}{|c|c|c|c|c|c|}
\hline Authors & Title & Journal (year) & Country & The Subgroup of Study & Conclusions \\
\hline $\begin{array}{c}\text { Jyotishi, Fein, } \\
\text { and Naigles } \\
{[13]}\end{array}$ & $\begin{array}{l}\text { Investigating the } \\
\text { grammatical and } \\
\text { pragmatic origins } \\
\text { of Wh-questions in } \\
\text { children with autism } \\
\text { spectrum disorders }\end{array}$ & $\begin{array}{l}\text { Frontiers in Psychology } \\
\qquad(2017)\end{array}$ & USA & $\begin{array}{c}\text { Comparison between } \\
\text { groups }\end{array}$ & $\begin{array}{l}\text { The "grammatical-origins" } \\
\text { argument is supported } \\
\text { because the ASD group } \\
\text { did not reveal earlier and } \\
\text { stable comprehension of } \\
\text { wh-questions; further- } \\
\text { more, their performance } \\
\text { on SVO word order pre- } \\
\text { dicted their later success in } \\
\text { the linguistic processing of } \\
\text { wh-questions. }\end{array}$ \\
\hline $\begin{array}{c}\text { Conti-Rams- } \\
\text { den, Simkin, } \\
\text { and Botting } \\
\qquad 14]\end{array}$ & $\begin{array}{l}\text { The prevalence of } \\
\text { autistic spectrum } \\
\text { disorders in adoles- } \\
\text { cents with a history } \\
\text { of Specific Language } \\
\text { Impairment (SLI) }\end{array}$ & $\begin{array}{l}\text { The Journal of Child } \\
\text { Psychology and Psy- } \\
\text { Chiatry (2006) }\end{array}$ & UK & $\begin{array}{l}\text { Comparison between } \\
\text { ASD and SLI }\end{array}$ & $\begin{array}{l}\text { Young people with SLI } \\
\text { have an increased risk } \\
\text { of autism. In addition, a } \\
\text { larger proportion present } \\
\text { with several behaviors } \\
\text { consistent with autism } \\
\text { spectrum disorders. }\end{array}$ \\
\hline Bishop [15] & $\begin{array}{l}\text { Pragmatic language } \\
\text { impairment: A } \\
\text { correlate of SLI, a } \\
\text { distinct subgroup, or } \\
\text { part of the autistic } \\
\text { continuum? }\end{array}$ & $\begin{array}{l}\text { Speech and Language } \\
\text { Impairments in Chil- } \\
\text { dren (2014) }\end{array}$ & USA & $\begin{array}{l}\text { Comparison between } \\
\text { ASD and SLI }\end{array}$ & $\begin{array}{l}\text { SLI is an exclusion-based } \\
\text { description of children } \\
\text { who have language } \\
\text { impairments, but also have } \\
\text { normal cognitive ability } \\
\text { and no identifiable cause } \\
\text { for their difficulties. }\end{array}$ \\
\hline $\begin{array}{l}\text { McGregor et } \\
\text { al. [16] }\end{array}$ & $\begin{array}{l}\text { Associations be- } \\
\text { tween syntax and } \\
\text { the lexicon among } \\
\text { children with or } \\
\text { without ASD and } \\
\text { language impair- } \\
\text { ment }\end{array}$ & $\begin{array}{l}\text { Journal of Autism } \\
\text { and Developmental } \\
\text { Disorders (2012) }\end{array}$ & USA & $\begin{array}{l}\text { Comparison between } \\
\text { ASD and SLI }\end{array}$ & $\begin{array}{l}\text { Children with autism plus } \\
\text { concomitant syntactic } \\
\text { language impairments per- } \\
\text { formed similarly to peers } \\
\text { with Specific Language } \\
\text { Impairment (SLI). }\end{array}$ \\
\hline
\end{tabular}

Kjelgaard An investigation of

ment in autism: Implications for genetic subgroups
Language and Cognitive Processes (2001)
USA

Comparison between

ASD and SLI

The profile of performance across the standardized measures for the language-impaired children with autism was similar to the profile that defines the disorder-specific language impairment.

\begin{tabular}{|c|c|c|c|c|c|}
\hline $\begin{array}{l}\text { Riches et al. } \\
\qquad[18]\end{array}$ & $\begin{array}{l}\text { Sentence repetition } \\
\text { in adolescents with } \\
\text { specific language } \\
\text { impairments and } \\
\text { autism: An investiga- } \\
\text { tion of complex } \\
\text { syntax }\end{array}$ & $\begin{array}{l}\text { International Journal } \\
\text { of Language \& Com- } \\
\text { munication Disorders } \\
\text { (2010) }\end{array}$ & UK & $\begin{array}{c}\text { Comparison between } \\
\text { ASD and SLI }\end{array}$ & $\begin{array}{l}\text { Adolescents with specific } \\
\text { language impairments may } \\
\text { have more severe syntactic } \\
\text { difficulties than adoles- } \\
\text { cents with autism plus } \\
\text { language impairment. }\end{array}$ \\
\hline $\begin{array}{l}\text { Whitehouse, } \\
\text { Barry, and } \\
\text { Bishop [19] }\end{array}$ & $\begin{array}{l}\text { The broader lan- } \\
\text { guage phenotype of } \\
\text { autism: A compari- } \\
\text { son with specific lan- } \\
\text { guage impairment }\end{array}$ & $\begin{array}{l}\text { Journal of Child Psy- } \\
\text { chology and Psychiatry } \\
\text { (2007) }\end{array}$ & UK & $\begin{array}{c}\text { Comparison between } \\
\text { ASD and SLI }\end{array}$ & $\begin{array}{l}\text { No evidence was found } \\
\text { proving a shared pheno- } \\
\text { type in parents of children } \\
\text { with ASD and SLI. }\end{array}$ \\
\hline $\begin{array}{l}\text { Baron-Cohen } \\
\qquad[20]\end{array}$ & $\begin{array}{l}\text { The autistic child's } \\
\text { theory of mind: A } \\
\text { case of specific de- } \\
\text { velopmental delay }\end{array}$ & $\begin{array}{l}\text { Journal of Child Psy- } \\
\text { chology and Psychiatry } \\
\text { (1989) }\end{array}$ & UK & $\begin{array}{l}\text { Grammar and theory of } \\
\text { mind }\end{array}$ & $\begin{array}{l}\text { Children with autism, in } \\
\text { comparison to Down syn- } \\
\text { drome and normal control } \\
\text { groups, were found to be } \\
\text { severely impaired at the } \\
\text { higher level of TOM. }\end{array}$ \\
\hline
\end{tabular}




\begin{tabular}{|c|c|c|c|c|c|}
\hline Authors & Title & Journal (year) & Country & The Subgroup of Study & Conclusions \\
\hline Happe [21] & $\begin{array}{l}\text { The role of age and } \\
\text { verbal ability in the } \\
\text { theory of mind task } \\
\text { performance of sub- } \\
\text { jects with autism }\end{array}$ & $\begin{array}{l}\text { Child Development } \\
\text { (1995) }\end{array}$ & UK & $\begin{array}{l}\text { Grammar and theory of } \\
\text { mind }\end{array}$ & $\begin{array}{l}\text { The analysis suggested } \\
\text { that children with autism } \\
\text { required far higher verbal, } \\
\text { mental age to pass false } \\
\text { belief tasks than did other } \\
\text { subjects. }\end{array}$ \\
\hline $\begin{array}{c}\text { Lind and } \\
\text { Bowler [22] }\end{array}$ & $\begin{array}{l}\text { Language and } \\
\text { theory of mind in } \\
\text { autism spectrum } \\
\text { disorder: The rela- } \\
\text { tionship between } \\
\text { complement syntax } \\
\text { and false belief task } \\
\text { performance }\end{array}$ & $\begin{array}{l}\text { Journal of Autism } \\
\text { and Developmental } \\
\text { Disorders (2009) }\end{array}$ & UK & $\begin{array}{l}\text { Grammar and theory of } \\
\text { mind }\end{array}$ & $\begin{array}{l}\text { The correlation between } \\
\text { complement syntax score } \\
\text { and location change task } \\
\text { performance was signifi- } \\
\text { cantly stronger within the } \\
\text { autism group than within } \\
\text { the comparison group. }\end{array}$ \\
\hline $\begin{array}{l}\text { Tager-Flusberg } \\
\text { [23] }\end{array}$ & $\begin{array}{l}\text { Identifying neuro- } \\
\text { cognitive pheno- } \\
\text { types in autism }\end{array}$ & $\begin{array}{l}\text { Biological Sciences } \\
\text { (2003) }\end{array}$ & USA & $\begin{array}{c}\text { Cognitive processing of } \\
\text { grammar }\end{array}$ & $\begin{array}{l}\text { There are two kinds of } \\
\text { subtypes in autism that are } \\
\text { defined based on language } \\
\text { profiles or cognitive } \\
\text { profiles. }\end{array}$ \\
\hline $\begin{array}{l}\text { Just et al. } \\
\text { [24] }\end{array}$ & $\begin{array}{l}\text { Cortical activation } \\
\text { and synchronization } \\
\text { during sentence } \\
\text { comprehension in } \\
\text { high-functioning } \\
\text { autism }\end{array}$ & Brain (2004) & USA & $\begin{array}{c}\text { Cognitive processing of } \\
\text { grammar }\end{array}$ & $\begin{array}{l}\text { The neural basis of disor- } \\
\text { dered language in autism } \\
\text { entails a lower degree of } \\
\text { information integration } \\
\text { and synchronization across } \\
\text { the large scale cortical } \\
\text { network for language } \\
\text { processing. }\end{array}$ \\
\hline $\begin{array}{l}\text { Baron-Cohen } \\
\text { et al. [25] }\end{array}$ & $\begin{array}{l}\text { Are children with } \\
\text { autism blind to the } \\
\text { mentalistic signifi- } \\
\text { cance of the eyes? }\end{array}$ & $\begin{array}{l}\text { British Journal of De- } \\
\text { velopmental Psychol- } \\
\text { ogy (1995) }\end{array}$ & UK & $\begin{array}{c}\text { Cognitive processing of } \\
\text { grammar }\end{array}$ & $\begin{array}{l}\text { While normal children } \\
\text { and children with mental } \\
\text { handicaps showed a } \\
\text { preference for eye-direc- } \\
\text { tion over an unnatural } \\
\text { cue when inferring these } \\
\text { mental states, children } \\
\text { with autism did not. }\end{array}$ \\
\hline $\begin{array}{l}\text { Mottorn et al. } \\
{[26]}\end{array}$ & $\begin{array}{l}\text { Enhanced percep- } \\
\text { tual functioning in } \\
\text { autism: An update, } \\
\text { and eight principles } \\
\text { of autistic percep- } \\
\text { tion }\end{array}$ & $\begin{array}{l}\text { Journal of Autism } \\
\text { and Developmental } \\
\text { Disorders (2006) }\end{array}$ & Canada & $\begin{array}{c}\text { Cognitive processing of } \\
\text { grammar }\end{array}$ & $\begin{array}{l}\text { Increased perceptual ex- } \\
\text { pertise may be implicated } \\
\text { in the choice of exception- } \\
\text { al ability in savant autistics. } \\
\text { The over-functioning of } \\
\text { brain regions typically in- } \\
\text { volved in primary percep- } \\
\text { tual functions may explain } \\
\text { the autistic perceptual } \\
\text { endophenotype. }\end{array}$ \\
\hline
\end{tabular}

Processes of language acquisi-

Swensen, Kelley, and Naigles [27] tion in children with autism: Evidence from preferential
Child Development (2007) looking

\section{Abstract reasoning}

Minshew in autism: A disasMeyer, Gold- sociation between stein [28] concept formation and concept identification.
The comprehension of word order in both groups well before production. Comprehension preceding creation appears to be robust processes of language acquisition, observable in both typical and languageimpaired populations.

Factor analyses showed that concept formation and concept identification tasks loaded on separate factors in the autism group but not in the control group. 


\section{Wh-questions}

One of the essential grammatical structures is Wh-questions. Each grammatical structure plays two roles: the grammatical role and the pragmatic role. In a pragmatic sense, the Wh-questions seek the information which the speaker is not aware of, and the speaker assumes that the addressee has information about them. Children begin asking "where" and "what" questions when they are between 27 to 29 months old [16]. Answering the questions usually decreases in children with ASD; also, the production of Wh-questions is sparse. It seems that answering the questions is one of the main components of the conversation. Because of the low number of questions and answers in these children, their parents and other relatives try to limit the complexity of questions to the yes/no questions. So, a suitable conversation will not be formed among them. For planning an effective intervention, we should find the causes of impairments, and it is essential to note that the comprehension and production of the Wh-questions of children with ASD are whether based on the grammatical problems or pragmatic disorders.

Tager-Flusberg [17] suggested that the problems of children with ASD in using the Wh-questions have more resulted from the pragmatic disorders because their questions were generally formed grammatically well. Sometimes, children with ASD act differently from TD children in the number and complexity of Wh-questions. They use a complicated form of a Wh question while they do not use its simpler form. They do not always comprehend the complex structures but produce them and only learn them as a whole [9]. Goodwin, Fein, and Naigles [18] suggested that the best way for assessing Wh-questions is a comprehension task in children with ASD because the comprehension task needs less social interaction. If children with ASD act weak in comprehension task, both pragmatic and grammar deficiencies can be blamed for Wh-questions problems.

They used Intermodal Preferential Looking (IPL), applied to evaluate the words and sentence comprehension that required low cognitive, social, and motor needs. Also, they examined the production of Wh-questions and their results showed that the majority of children with ASD had a stable comprehension of the Wh-questions. However, the usage of these questions was rarely seen in the everyday conversation of these children. This study showed that children with ASD could learn some grammatical rules of Wh-questions such as a sentence format without Subject Verb Object (SVO) order or a Wh-question which replaced a deleted noun clause, but the production of Wh-questions decreased.
Jyotishi, Fein, and Naigles used the IPL method for evaluating Wh-questions comprehension. Their findings indicated that the children with ASD had no stable comprehension of these questions, and both grammar and social-pragmatic factors were considered as the reason for Wh-questions problems. They suggested that the communication and social interaction of children with ASD could predict their successful performance in comprehending Wh-questions [19]

Comparison of grammatical characteristics in children with autism spectrum disorder and children with specific language impairment

One of the most challenging discussions in the recent decades is that the language impairments which are frequently observed in children with ASD is one of the main signs of this disorder or resulted from the comorbidity with other disorders like SLI. Findings indicate that ASD incidence is about $3.9 \%$ among the adults that have been diagnosed with SLI before-10 times more than TD children. In other words, the risk of occurring ASD in individuals with SLI is high and significant [20].

SLI is a developmental disorder in which the children show impairments in language abilities, with no sensory, cognitive, or mental impairments [21]. Children with SLI have more problems in syntax than semantics and words. Also, the deficiencies in the semantic-word system are more than pragmatics; i.e. the syntax is the main problem. The short sentence length, deletion of grammatical morphemes, and limited knowledge in the argument structures are seen in children with SLI [22]. There are different opinions about the relationship between SLI and ASD. Some studies express that ASD and SLI are two separated and various disorders that can frequently occur together, i.e. comorbidity. This term is used when there is a cognitive overlap, while these two disorders occur entirely separated from each other [23]. Kjelgaard and Tager-Flusberg reported the impaired structural language in all children with SLI might be very small or negligible in children with ASD [24]

Riches et al. [25] examined the sentence repetition ability in adults with ASD and SLI. The sentence repetition is an essential task for diagnosing children with SLI from other disorders. When people repeat sentences longer than their memory capacity, they use not only their short-term memory but also the semantic-syntactic knowledge to facilitate the reminding process. Individuals can use short-term memory for just repetition without comprehending the sentence meaning. When the sentence length is longer than short-term memory capac- 
ity, the people must understand the sentence to repeat it. Riches et al. used complex syntax sentences in their study. Based on their obtained results, the profiles of the two groups were qualitatively similar and the syntax complexity increased errors. Therefore, children with ASD showed the same syntactic deficiencies as children with SLI showing the overlap between these two groups; of course, the SLI was affected more.

Rapin recommended a subgroup with semantic-pragmatic disorder. The individuals showed problems in the social usage of language, and their profile of the deficiencies was the average of SLI and ASD. He called this subgroup Pragmatic Language Impairment (PLI) [26].

Some researchers like Whitehouse believed that the ASD and SLI groups demonstrated the common features; however, the basis of their deficiencies was different. For example, the deficiency in the non-word repetition task in ASD is qualitatively different from SLI, and no evidence proves that these two disorders were dependent on etiology or symptoms [27].

The relationship between grammar and theory of mind in children with autism spectrum disorder

Theory of Mind (TOM) attributes the mental statements like beliefs and wishes to the owner and the others to interpret and to predict the behaviors [28]. TOM is impaired in children with ASD due to social and communication deficiencies, and this impairment is one of the main characteristics of ASD [29]. During the preschool ages, the TOM ability gets more and more complex, and the children can comprehend the false beliefs at around four years old. Two common false belief tasks consist of the unseen displacement [30] and the unexpected contents [31]. Children with ASD usually are unable to do such tasks, and many studies report that the ASD group has a problem in doing the TOM task. However, some can do such tasks despite social and communicational deficiencies [32]. They seemingly use a compensatory procedure without using the TOM strategies or a different process compared with the TD children. The studies showed a strong relationship between language and performance in the TOM tasks in children with ASD [33].

Based on these studies, a special kind of grammatical capability called complement syntax can facilitate the performance of children with ASD in doing the TOM tasks. De Villier and Pyers [34] reported that when children acquire this level of grammar, their ability to do false belief tasks increases. Complementation is a syntactic process in which one phrase encompasses another phrase. Two groups of verbs that can include another phrase are communicational verbs (say, tell) and mental state verbs (think, believe). Consider this sentence: "He thought that the stone is in the box while the stone was in the basket". In the first sentence in which a phrase placed into another, there is a probability of its right or wrong and surely, it does not point to the fact. Therefore, false beliefs can be shown in these sentences.

In a linear study, De Villier and Pyers examined the relationship between the complement syntax and TD children's performance in doing false belief tasks. According to his idea, the complement syntax can be used to decode the false belief. Although this ability does not mean the TOM capability, it is an important step to develop the TOM in TD children to be able to justify the mental statements [34]. Some children with ASD may use the complement structures knowledge to facilitate doing the false belief task while their TOM ability has not been completed yet. Tager-Flusberg and Joseph examined the association between the complement syntax and the performance in doing TOM tasks in children with ASD [33]. Their findings showed a positive relationship between the mentioned variables.

Lind and Bowler used the complement syntax memory and the Sali and Annie situation changing task (unseen displacement task), as well as the unexpected content task of Ismartiz. The results indicated that in the ASD group, there is a relationship between the Sali and Annie task and the complement syntax ability. However, this relationship was not seen in the Ismartiz task. The cause of the difference between these two tasks is the different cognitive and linguistic needs. The Sali and Annie task has a storytelling format and uses the simpler forms of Wh-questions, while the Ismartiz task is entirely different and includes more complex questions [35].

The processing basis of grammatical characteristics in children with autism spectrum disorder

\section{The procedural memory deficit hypothesis}

According to this theory, some of the problems in linguistic and motor skills in the ASD group are because of deficiency in the neural structures like basal ganglia and frontal cortex. In other words, deficiency in the procedural memory resulted from the performances of these areas [36]. One of the theoretical aspects of language is the dual system model distinguishing mental lexical and mental grammar and expresses that these two linguistic skills depend on the two separated memory systems. Lexicon is learned through the declarative memory lo- 
cated on the temporal lobe, and learning grammar depends on the procedural memory resulted from the performance of the frontal lobe and basal ganglia. In this dual system, the mental lexicon is a significant source of information, such as the relationship between the word phonetics and its meaning.

The irregular verbs are placed in this source too; in contrast, the mental grammar is a rule-governed system making the longer words and structures like complex words, phrases, sentences by compounding smaller linguistic elements like morphemes. For example, the regular past tense verbs in which the root compounds with a suffix are made in the mental grammar system. To produce the past tense, the brain circuits simultaneously search a saved form in the mental lexical system and the grammatical rule usage to add "ed" suffix to the root.

The two processes continue till one inhibits another. If the search in the lexical system is successful, the past form is retrieved from the lexicon, and the rule-based output will stop but if the inflected form is not retrieved from the lexicon, the rule-based output will be produced. So, regular and irregular verbs have different cognitive processes and use different brain structures [37]. If the theory of deficiency in the procedural memory in children with ASD is right, so we must expect that these individuals show a problem with producing the regular forms. Depending on the modality of the basal ganglia damage, this abnormal production may appear in the different forms. For example, accuracy decreases or the reaction time to the regular verbs gets slower such as Huntington disorder or Turret syndrome.

The faster reaction time with less accuracy in the sentence comprehension task was reported in children with ASD. Also, their functional magnetic resonance imaging showed that the brain simultaneous activation with comprehending the active and passive sentences was different from the TD group and the activation was less in the Broca (the left bottom frontal gyros) area [38].

Walenski, Mostofsky, and Ullman [3] examined the production of inflected forms of the regular and irregular verbs in children with ASD and evaluated both accuracy and reaction time in the grammar and lexical process. For implementing the test, the subjects were asked to produce the past tense of the given verbs in the form of the written sentences (Every day, I dig a hole; yesterday I ... a hole). There was no difference in producing the regular and irregular verbs in the groups. Whereas, there were significant differences in the reaction time between two groups and the children with ASD were faster than the control group. The results of this study indicated processing differences between the ASD group and the TD group because of deficiency in the procedural memory.

\section{The priority of comprehension to production hypothesis}

The TD children are initially able to comprehend the grammatical structures and words and then produce them. In other words, what they hear analyze before using that in the conversation. This phenomenon shows that learning linguistic forms does not depend on their production ability in TD children [39]. Also, the experimental studies indicate that children comprehend the role of Wh-questions and the sentence order sooner than their producing [40]. Some studies suggest that the production is before comprehension in individuals with ASD, and they analyze what they have already said. They do not follow the speaker's eyes while producing a new word, so the new words are as strange things rather than familiar [41]. These findings demonstrate that children with ASD may use a different processing method in the acquisition of language, and they should produce some linguistic aspects to learn them thoroughly [42]. However, some studies believed the word comprehension is before production in children with ASD, and at least, their necessary process of language acquisition is the same as TD children $[18,43]$.

The hypothesis of deficiency in the syntactic bootstrapping

The critical point about grammar is that the grammatical structures are abstract [44]. Being abstract can be a challenge for children with ASD. They cannot generalize a grammatical rule beyond what is taught [45]. There are two ways to examine to what extent grammar knowledge is abstract in children with ASD. The first is the evaluation of the child's spontaneous speech and examining how much he or she uses the grammatical structures. The second and more suitable way is the use of a task in which the child guesses the meaning of a non-word through the interpretation of the grammatical structure. For example, transitive verbs need an object (He threw the ball.) while intransitive verbs do not require that. (The ball fell.) So, if we say "she is blicking a doll", and at the same time, a child is carrying a doll, it seems that the "blick" as a non-word means "carrying" but when in the same situation, we say "she is blicking", it appears that it means she is walking. This process is called Syntactic Bootstrapping (SB), which includes the integrity of the syntax/visual/spatial information during the learning process. SB is one of the main processes of 
linguistic development in the TD children used for learning nouns, verbs, and adjectives [43].

It seems that the language of children with ASD is not abstract because they use language structures in a particular context or item, and there is no creativity in their spontaneous speech [9]. Naigles and Tek [6] examined whether children with ASD could learn the meanings of new verbs through the SB process. The results showed that the ASD group used the SB process like TD children. These findings suggest that some children with ASD can make the grammatical structures abstract.

\section{Discussion}

In this retrospective study, we reviewed the grammatical characteristics of children with ASD. The authors categorized the studies into four subgroups based on the research question. The results of the studies were conflicting because of two main factors: differences in the type of studies and heterogeneity in the studied children with ASD.

\section{The type of studies}

The studies used a different method for gathering the linguistic data; each method may have different needs, including cognitive needs or communicational needs that affect the test results [9].

One of the main features of children with ASD is impaired communication, so a low score of a sample obtained through the free game can result from the communicational problems. Also, in the most applicable methods, particularly in conversation, it is hard to distinguish between grammar deficiencies and other linguistic aspects like pragmatic disorders. That is a problem because we should seek the underlying problem to plan appropriate treatment. Therefore, the methods that need less communication skills like grammar judgment task or IPL method are more suitable. Of course, these methods are only able to evaluate grammatical comprehension, and we should be sure that the participant comprehends the task. To assess the production of the grammatical structure, it seems that the sentence repetition task is suitable. When the sentence length is longer than the capacity of the short-term memory, the subject should use the syntactic and semantic knowledge to remind the sentence. Therefore, the usage of complex sentences is recommended.

Another reason for the different findings is the homogenization of the studied groups. For example, the non-verbal ability is often the strength point of children with ASD, and when the groups are homogenized based on their verbal skills, the child's cognitive ability can bring about a better performance in the linguistic tests [33]. Therefore, non-verbal intelligence is an essential factor for homogenizing the matching groups. For comparing the grammatical characteristics, it is better to homogenize all groups in terms of all linguistic aspects such as the comprehension language and lexicon to assure that the differences between groups do not result from the other factors.

The different age ranges can be considered as another factor; the age range was extreme in some studies. As grammar ability depends on the growth, it is better to select a more limited age range.

\section{Autism spectrum disorder group as a heteroge- neous group}

Children with ASD are a very heterogeneous group; some of them show age-appropriate language and cognitive abilities while some are non-verbal. Wittke et al. [11] categorized the children with ASD in three groups: the children with typical language, the children with certain impairment in grammatical production but with a relatively normal lexicon, and the children whose linguistic ability is meager. Thus, we suggest that the linguistic skills of children with ASD be evaluated with more details.

The relationship between autism spectrum disorder and specific language impairement

One of the other questions of the present study is the relationship between ASD and SLI. The differential diagnosis of these two disorders in the lower ages is critical because it affects the prognosis and treatment. Two theories are mentioned: the first theory suggests that ASD and SLI are two separated disorders frequently cooccur and have high comorbidity. The second theory indicates that some people can be placed both in the ASD group and SLI group, and the profile of their deficiency is in the middle of ASD and SLI, which is called PLI. It is recommended that during the disorder evaluation and the recognition, this point is considered that which linguistic aspect is more deficient. In children with ASD, pragmatic skill is more damaged, while in children with SLI, the language structure is deficient more.

The relationship between grammar and theory of mind in children with autism spectrum disorder

Deficiency in TOM is one of the fundamental impairment in children with ASD, but some individuals in this 
group act successfully in the false belief tasks despite a deficiency in the communicational and social abilities. The studies suggest that these individuals reach the answer of the task by using a compensating procedure with the verbal intermediate and without applying TOM. A special kind of analytical capability called complement syntax can facilitate the ASD's performance in the task of TOM. To prove the relationship between the complement syntax and the TOM, we recommend to teach this grammatical structure to children with ASD and examine its effect on the TOM task.

The processing basis

In the present study, we mentioned three hypotheses related to the children with ASD and the grammar learning: the hypothesis of deficiency in the procedural memory, the priority of comprehension to production hypothesis, and the hypothesis of deficiency in the syntactic bootstrapping. When the process paths are studied, some points should be considered. It is better to study two genders separately because the language process for the two genders was different [3]. Another point is the use of assessment tools like functional magnetic resonance imaging in addition to linguistic-cognitive tests to improve the accuracy of the findings. There are a few studies in the field of the process paths, so more evaluation of the mentioned studies is recommended. Proving each theory has a significant influence on the assessment and intervention for children with ASD.

\section{Conclusions}

A group of children with ASD showed impairments in the structural language like grammar. A variety of grammatical impairments are seen in children with ASD. As a result, it is necessary to study this aspect of language accurately because it helps to plan an effective intervention. Our review of the literature showed the conflicting and sparse results with different viewpoints, and we suggest more studies to clear the discrepancy in results.

The results of the present study can help better understand the grammatical characteristics in children with ASD, and finally design an effective intervention for this aspect of language. We recommend that future studies investigate the grammatical structures of language separately with more details in children with ASD, and considered the cross-linguistic studies.

\section{Ethical Considerations}

\section{Compliance with ethical guidelines}

This article does not contain any studies involving human and animals' participants performed by any of the authors.

Funding

This research did not receive any specific grant from funding agencies in the public, commercial, or not-forprofit sectors.

\section{Authors contributions}

Data collection and analysis: Saeide Beytollahi; Conceptualization, investigation, and supervision: Zahra Soleymani; Writing-original draft preparation, writing -review \& editing, visualization: Saeide Beytollahi, Zahra Soleymani.

\section{Conflict of interest}

The authors declared no conflict of interest.

\section{References}

[1] American Psychiatric Association. Diagnostic and statistical manual of mental disorders. $5^{\text {th }}$ ed. (DSM- $\left.5^{\circledR}\right)$. Washington, D.C., United States: American Psychiatric Pub; 2013. [DOI:10.1176/appi.books.9780890425596]

[2] Volden J, Phillips L. Measuring pragmatic language in speakers with autism spectrum disorders: Comparing the Children's Communication Checklist-2 and the Test of Pragmatic Language. American Journal of Speech-Language Pathology; 2010; 19(3). [DOI:10.1044/1058-0360(2010/09-0011)]

[3] Walenski M, Mostofsky SH, Ullman MT. Inflectional morphology in high-functioning autism: Evidence for speeded grammatical processing. Research in Autism Spectrum Disorders. 2014; 8(11):1607-21. [DOI:10.1016/j. rasd.2014.08.009] [PMID] [PMCID]

[4] Cohen DJ, Volkmar FR. Handbook of autism and pervasive developmental disorders. Hoboken, New Jersey: John Wiley \& Sons Inc; 1997.

[5] Pinker S, Ullman M. Combination and structure, not gradedness, is the issue. Trends in Cognitive Sciences. 2002 6(11):472-4. [DOI:10.1016/S1364-6613(02)02013-2]

[6] Naigles LR, Tek S. 'Form is easy, meaning is hard' revisited: Characterizing the strengths and weaknesses of language in children with autism spectrum disorder. Wiley Interdisciplinary Reviews: Cognitive Science. 2017; 8(4):e1438 [DOI:10.1002/wcs.1438] [PMID] 
[7] Tager-Flusberg, H. Calkins, S. Does imitation facilitate the acquisition of grammar? Evidence from a study of autistic, Down's syndrome and normal children. Journal of Child Language, 1990; 17(3):591-606. [DOI:10.1017/S0305000900010898] [PMID]

[8] Brynskov C, Eigsti IM, Jørgensen M, Lemcke S, Bohn OS, Krøjgaard P. Syntax and morphology in Danish-speaking children with Autism Spectrum Disorder. Journal of $\mathrm{Au}-$ tism and Developmental Disorders. 2017; 47(2):373-83. [DOI:10.1007/s10803-016-2962-7] [PMID]

[9] Eigsti IM, Bennetto L, Dadlani MB. Beyond pragmatics: Morphosyntactic development in autism. Journal of Autism and Developmental Disorders. 2007; 37(6):1007-23. [DOI:10.1007/ s10803-006-0239-2] [PMID]

[10] Eigsti IM, Bennetto L. Grammaticality judgments in autism: Deviance or delay. Journal of Child Language. 2009; 36(5):999-1021. [DOI:10.1017/S0305000909009362] [PMID]

[11] Wittke K, Mastergeorge AM, Ozonoff S, Rogers SJ, Naigles LR. Grammatical language impairment in autism spectrum disorder: Exploring language phenotypes beyond standardized testing. Frontiers in Psychology. 2017; 8:532. [DOI:10.3389/fpsyg.2017.00532] [PMID] [PMCID]

[12] Rapin I, Dunn M. Update on the language disorders of individuals on the autistic spectrum. Brain and Development. 2003; 25(3):166-72. [DOI:10.1016/S0387-7604(02)00191-2]

[13] Fein D, Waterhouse L. Autism is not a disorder of language. Boston: The New England Child Language Association; 1979.

[14] Pierce S, Bartolucci G. A syntactic investigation of verbal autistic, mentally retarded, and normal children. Journal of Autism and Childhood Schizophrenia. 1977; 7(2):121-34. [DOI:10.1007/BF01537724] [PMID]

[15] Bartolucci G, Pierce SJ, Streiner D. Cross-sectional studies of grammatical morphemes in autistic and mentally retarded children. Journal of Autism and Developmental Disorders. 1980; 10(1):39-50. [DOI:10.1007/BF02408431] [PMID]

[16] Stromswold K. The acquisition of subject and object whquestions. Language Acquisition. 1995; 4(1-2):5-48. [DOI:10.1 080/10489223.1995.9671658]

[17] Tager-Flusberg H. Dissociations in form and function in the acquisition of language by autistic children. Constraints on language acquisition: Studies of Atypical Children. 1994 17594 .

[18] Goodwin A, Fein D, Naigles LR. Comprehension of whquestions precedes their production in typical development and autism spectrum disorders. Autism Research. 2012; 5(2):109-23. [DOI:10.1002/aur.1220] [PMID] [PMCID]

[19] Jyotishi M, Fein D, Naigles L. Investigating the grammatical and pragmatic origins of wh-questions in children with autism spectrum disorders. Frontiers in Psychology. 2017; 8:319. [DOI:10.3389/fpsyg.2017.00319] [PMID] [PMCID]

[20] Conti-Ramsden G, Simkin Z, Botting N. The prevalence of autistic spectrum disorders in adolescents with a history of Specific Language Impairment (SLI). Journal of Child Psychology and Psychiatry. 2006; 47(6):621-8. [DOI:10.1111/ j.1469-7610.2005.01584.x] [PMID]

[21] Bishop DV. Pragmatic language impairment: A correlate of SLI, a distinct subgroup, or part of the autistic continuum? In
Speech and Language Impairments in Children. Psychology Press. 2014; 23:113-28.

[22] McGregor KK, Berns AJ, Owen AJ, Michels SA, Duff D, Bahnsen AJ, et al. Associations between syntax and the lexicon among children with or without ASD and language impairment. Journal of Autism and Developmental Disorders. 2012; 42(1):35-47. [DOI:10.1007/s10803-011-1210-4] [PMID] [PMCID]

[23] Tomblin JB, Zhang X. The dimensionality of language ability in school-age children. Journal of Speech, Language, and Hearing Research. 2006; 49(6):1193-208. [DOI:10.1044/10924388(2006/086)]

[24] Kjelgaard MM, Tager-Flusberg H. An investigation of language impairment in autism: Implications for genetic subgroups. Language and Cognitive Processes. 2001; 16(2-3):287308. [DOI:10.1080/01690960042000058] [PMID] [PMCID]

[25] Riches NG, Loucas T, Baird G, Charman T, Simonoff E. Sentence repetition in adolescents with specific language impairments and autism: An investigation of complex syntax. International Journal of Language \& Communication Disorders. 2010; 45(1):47-60. [DOI:10.3109/13682820802647676] [PMID]

[26] Rapin I. Practitioner review: Developmental language disorders: A clinical update. Journal of Child Psychology and Psychiatry. 1996; 37(6):643-55. [DOI:10.1111/j.1469-7610.1996. tb01456.x] [PMID]

[27] Whitehouse AJ, Barry JG, Bishop DV. The broader language phenotype of autism: A comparison with specific language impairment. Journal of Child Psychology and Psychiatry. 2007; 48(8):822-30. [DOI:10.1111/j.1469-7610.2007.01765.x] [PMID] [PMCID]

[28] Premack D, Woodruff G. Does the chimpanzee have a theory of mind? Behavioral and Brain Sciences. 1978; 1(4):515-26. [DOI:10.1017/S0140525X00076512]

[29] Baron-CohenS. The autistic child's theory of mind: A case of specific developmental delay. Journal of child Psychology and Psychiatry. 1989; 30(2):285-97. [DOI:10.1111/j.1469-7610.1989. tb00241.x] [PMID]

[30] Wimmer H, Perner J. Beliefs about beliefs: Representation and constraining function of wrong beliefs in young children's understanding of deception. Cognition. 1983; 13(1):103-28. [DOI:10.1016/0010-0277(83)90004-5]

[31] Perner J, Leekam SR, Wimmer H. Three-year-olds' difficulty with false belief: The case for a conceptual deficit. British Journal of Developmental Psychology. 1987; 5(2):125-37. [DOI:10.1111/j.2044-835X.1987.tb01048.x]

[32] Happé FG. The role of age and verbal ability in the theory of mind task performance of subjects with autism. Child Development. 1995; 66(3):843-55. [DOI:10.2307/1131954] [PMID]

[33] Tager-Flusberg H, Joseph RM. Identifying neurocognitive phenotypes in autism. Philosophical transactions of the royal society of London. Series B: Biological Sciences. 2003; 358(1430):303-14. [DOI:10.1098/rstb.2002.1198] [PMID] [PMCID]

[34] De Villiers JG, Pyers JE. Complements to cognition: A longitudinal study of the relationship between complex syntax and false-belief-understanding. Cognitive Development. 2002; 17(1):1037-60. [DOI:10.1016/S0885-2014(02)00073-4] 
[35] Lind SE, Bowler DM. Language and theory of mind in autism spectrum disorder: The relationship between complement syntax and false belief task performance. Journal of Autism and Developmental Disorders. 2009; 39(6):929-37. [DOI:10.1007/s10803-009-0702-y] [PMID]

[36] Ullman MT. Contributions of memory circuits to language: The declarative/procedural model. Cognition. 2004; 92(12):231-70. [DOI:10.1016/j.cognition.2003.10.008] [PMID]

[37] Pinker S, Ullman M. Combination and structure, not gradedness, is the issue. Trends in Cognitive Sciences. 2002; 6(11):472-4. [DOI:10.1016/S1364-6613(02)02013-2]

[38] Just MA, Cherkassky VL, Keller TA, Minshew NJ. Cortical activation and synchronization during sentence comprehension in high-functioning autism: Evidence of underconnectivity. Brain. 2004; 127(8):1811-21. [DOI:10.1093/brain/awh199] [PMID]

[39] Snyder W. Child language: The parametric approach. London: Oxford University Press; 2007.

[40] De Villiers J. Empty categories and complex sentences: The case of wh-questions. Handbook of Child Language. Oxford: Blackwell Publishing; 1995. [DOI:10.1111/ b.9780631203124.1996.00021.x]

[41] Baron-Cohen S, Campbell R, Karmiloff-Smith A, Grant J, Walker J. Are children with autism blind to the mentalistic significance of the eyes? British Journal of Developmental Psychology. 1995; 13(4):379-98. [DOI:10.1111/j.2044835X.1995.tb00687.x]

[42] Mottron L, Dawson M, Soulieres I, Hubert B, Burack J. Enhanced perceptual functioning in autism: An update, and eight principles of autistic perception. Journal of Autism and Developmental Disorders. 2006; 36(1):27-43. [DOI:10.1007/ s10803-005-0040-7] [PMID]

[43] Swensen LD, Kelley E, Fein D, Naigles LR. Processes of language acquisition in children with autism: Evidence from preferential looking. Child Development. 2007; 78(2):542-57. [DOI:10.1111/j.1467-8624.2007.01022.x] [PMID]

[44] Tomasello M. Do young children have adult syntactic competence? Cognition. 2000; 74(3):209-53. [DOI:10.1016/S00100277(99)00069-4]

[45] Minshew NJ, Meyer J, Goldstein G. Abstract reasoning in autism: A disassociation between concept formation and concept identification. Neuropsychology. 2002; 16(3):327-34. [DOI:10.1037/0894-4105.16.3.327] [PMID] 
This Page Intentionally Left Blank 